\title{
Constructing the Teaching System of Military Academy and Improving the Quality of Military School Education in an All-round Way
}

\author{
Jiu-ling ZHAO* \\ Rocket Force University of motoring, Xi'an, PR, China \\ ${ }^{*}$ Corresponding author
}

Keywords: Construction, Teaching system, Quality of education, Military Academy.

\begin{abstract}
This paper mainly introduces how to build a military school teaching system scientifically, and guarantee and enhance the teaching quality of military academies, and cultivate more competitive military academy elites in the new situation, in order to meet the preparations for military struggle needs play in new period military readiness requirements and characteristics of the PLA.
\end{abstract}

\section{Introduction}

Military education is the training of military personnel main channel to improve the quality of officers and soldiers, is the cornerstone of the development of military construction, which plays an important role in the overall basic pilot in the modernization of the military construction and preparations for military struggle in the military academy education development and construction of informationization of army personnel demand the quality of talent training and the win is not completely. So to adapt to the requirement of information war quality, we must solve these problems with the development of ideas, scientific construction of the military teaching physique, improve the quality of education in military academies, colleges promote the scientific development of education scientific and reasonable teaching system should include the comprehensive quality of the teachers, scientific teaching methods and a series of perfect teaching quality guarantee system.

\section{Change the Teaching Idea and Clear the Teaching Goal People Oriented}

The quality of teachers directly affects the thought of the military education policy and policy implementation, directly affect the quality of military talents, to a certain extent determines the success or failure of the military education in the world new military reform and comprehensively promote the students quality education today, teachers' moral quality psychological quality education concept of humanistic quality of professional knowledge teaching the ability of force side must adapt to this new situation, the teacher must be professional talent to compound talents should have change, be a brilliant man of wide learning high professional quality, and reasonable knowledge structure has high humanistic quality [1].

In order to adapt to the new military transformation and leapfrog development, military academies should gradually education into professional education for vocational education teaching director of teaching and different teaching purpose, teaching content and teaching methods and teaching means with different so much, we should change the concept of teaching, teaching the target, targeted, planned to develop new situation for the cadets of military professional education teaching methods innovation should aim to promote the construction of effective and easy operation can meet the different needs of students into the object hierarchy and preparations for military struggle closely with the practice characteristic of the system and improve the quality of teaching and teaching methods means for the implementation of this goal, there should be a phased plan to gradually reform, do both near and far, not Seek the speed, only seek the actual effect [3]. 


\section{Building a Scientific and Reasonable Teaching System}

\section{Strengthening the Management of Teaching System and Improving the Quality Evaluation}

Perfect the teaching management regulations and build a scientific management system and effective operation mechanism innovation of teaching management, the teaching management system changed from closed to open, is the direction of the development of modern military management to achieve the transformation of management system change management by constraint to the incentive type by process type to the target type, in order to train the high-quality military personnel of in the information era, teaching means and management has gradually developed into the teaching management informatization establishment of modern information system of teaching management, teaching information is the military construction of [2] in our military academies should must leap in the teaching reform in the military academy.

\section{Optimizing Teaching Content, Improving Teaching Means and Innovating Teaching Methods}

The reform of the teaching method, is not an isolated body, teaching methods and teaching contents, training objectives three are closely linked in the teaching activities, using a variety of teaching methods, both teachers play a leading role, and fully mobilize the initiative and enthusiasm of students in addition to stimulate students interest in learning explicit learning the purpose, should also pay special attention to imparting knowledge and cultivating ability to combine, so that students in mastering the basic theory at the same time, to actively develop their intelligence, cultivate their self-learning ability expression ability of organization and management ability and the ability of analyzing and solving problems.

The primary task of post education is to cultivate students' ability to adapt to their positions. Only by relying on knowledge and inculcation can they fail to teach. Only by teaching professional knowledge, can students practice.

Experience and thinking can only be achieved through practice. Two is through observation, three is through comprehensive exercises, teaching should pay attention to the combination of theory and practice, try to carry out seminar teaching, interactive teaching mode, unified requirement and teach students in accordance with their aptitude.

\section{Taking Practical Teaching as the Leading Part and Promoting Case Teaching}

Combining theory with practice, highlighting the military application background with the development of military technology in the world and our military modernization, science and technology content of equipment is increasing, the synthesis degree increasing, accordingly, need strong strain of a large number of professional and technical ability of anti fine business should be fast disposal of knowledge problem quasi complex and creative talents. The case teaching can meet the training requirements from case teaching purposes, through the study of typical examples and case analysis, to deepen the understanding of professional knowledge, strengthen the integration of knowledge, improve business skills and practical ability; from the means of view, through the teaching method, open discussion of entertaining in order to improve the students, open thinking and creative thinking ability; from the perspective of its result, through both teaching To provide a template for future military personnel, so that they can refer to the use of control, control the future war disposal to make these high-quality people can be quickly and accurately judging from the perplexing situation, take out the solution accurately appropriately, shorten the transition from the ordinary student commander to high-quality military personnel, to provide human resources and intelligence resources for our military forces so as to promote the quality of the army, the revolutionary modernized and regularized.

At present, case based teaching has been widely applied in the teaching process of vocational education. However, people's understanding of case teaching seems to remain in the traditional stage. The great potential of this teaching mode in post education needs to be further explored in. 


\section{Harmonious Education Environment is an Effective Carrier of Education Development}

The harmonious educational environment shows the harmonious development of the teaching and non teaching factors in the school education environment. "Teaching factors" refer to various factors which are mainly based on classroom. "Non teaching factors" refer to the educational factors of campus culture, school running idea, system construction, school spirit and school appearance. The harmonious development of teaching factors and non teaching factors is the key factor and decisive factor to form the overall effect of the harmonious military school. The campus environment can have a silent effect of educating people, Sue Home Linsky said, to let the school every side of the wall will speak. Many buildings in the West Point are named after the famous American characters, such as the headquarters of the Washington Cadet building, named "sea power theory" Navy strategist Mahan the author of the Mahan building, and a large number of famous monuments, statues and the list of outstanding students, to motivate students honor and responsibility. Therefore, the establishment of honor rooms, celebrities and heroic statues can not only reflect the characteristics and demeanor of military schools, but also educate and motivate them in a good environment. At present, to strengthen the construction of harmonious education environment, we should focus on the improvement of the psychological environment and cultural environment.

In terms of the psychological environment of military academies, such as the nature of colleges, the scale of training, the facilities of the region, the structure of the organization, the faculty and so on, the construction of the psychological environment in military academies belongs to the military academy's "soft system" project.[3] It focuses on the psychological needs and behavior control of the environmental factors and state to the group, and focuses on the atmosphere design of the military school management. Such as the achievements and goals of psychological environment is through education and the control and management of the colleges and universities have achieved and the corresponding social status and reputation of colleges and positive development planning and other factors, the formation of the psychological environment of all members of a military and society full of expectations and confidence in the colleges. Psychological education environment is the core part of the psychological environment, it refers to the military academy ("3-styles" school spirit, teaching style and learning style, and to school education as the main line) management and control as the main elements, the formation of the traditional rich characteristics, and the military members in the "ideal psychological environment and traditional appeal the characteristics of personalized, enhance the concept of collectivism, improve military accomplishment, concentrate on their work, and consciously safeguard the college characteristic and reputation. The organizational psychological environment is mainly controlled by effective management, operation mechanism, rules and regulations, interpersonal relationships and other elements, so that this organizational atmosphere can standardize members' words and actions, generate incentive effect and improve work efficiency.

The materialized psychological environment in military academies is controlled by the general layout of campus external features such as school capacity, school appearance and so on, so that members of military academies not only feel open and comfortable, but also feel solemn and solemn in military academies, so as to reflect the deeds, norms and styles of Military Academies.[4] Our army has carried out grassroots cultural activities, to create a harmonious and elegant tradition, even in harsh war, also attaches great importance to the ideological and cultural construction of the army, never ignores the books, movies, theater songs of the army's education and influence, and healthy cultural activities in terms of morale, improve the combat effectiveness of play a great and irreplaceable role. We have the glorious tradition of troops to carry out grassroots cultural activities carry forward, and actively guide people to sing songs, read good books, good things, carry out a variety of rich and colorful, healthy cultural activities, the establishment of military culture, network culture provides a colorful world for soldiers, so they stay at home, not limited to time, listen to enjoy music, watch the game, celebrity calligraphy and painting, playing video games, browsing the world more wonderful local customs and practices on the Internet, the spiritual and cultural life, and efforts to improve the ideological consciousness and spiritual realm in entertaining. Strive to give its new 
connotation and the characteristics of the times to provide a strong spiritual motive for "win and not go bad".

\section{Summary}

The next 10 years, the information construction of the PLA will enter a new stage of accelerated development, military innovation and personnel training has become the leading factor to enhance the core military capability in the new situation, only the exploration, innovation, based on our existing military strength, scientific optimization of teaching resources, teaching methods, and constantly improve the strength of military education, in order to meet the preparations for military struggle needs play in new period military readiness requirements and characteristics of the PLA.

\section{References}

[1] Liu Yanan, Ho Qing, Talking about the application of case teaching in the teaching of military schools, Heilongjiang science and technology information. 21(2010) 12-15.

[2] Meng Dandan, Teaching method of optimizing and improving the teaching method of the military school, Scientific and technological information. 20(2008) 37-40.

[3] Wang Dexia, Xue, Wang Qin, Based on a high starting point of education, Ttraining and education of talents. naval college, 5(2001) 78-82.

[3] Sun Zhiqing, Relied on military education to cultivate talents, Political journal, 3 (1995) 45-52. 